\title{
Pengaruh Pemberian Pakan Flushing dan Non Flushing terhadap Intensitas Birahi dan Angka Kebuntingan Induk Sapi Potong
}

\section{The Effects of Flushing and Non Flushing on Oestrous Intensity and Conception of the Cow}

\author{
N. Rohmah, Y. S. Ondho dan D. Samsudewa \\ Fakultas Peternakan dan Pertanian, Universitas Diponegoro \\ Kampus drh. R. Soedjono Koesoemowardjojo Tembalang Semarang 50275 \\ Email : nurrohmah68@gmail.com ; daudreproduksi@gmail.com
}

\begin{abstract}
The aim of this research was to determine the effect of flushing and non-flushing on oestrous intensity and conception of the cow. There were 22 cows (12 SimPO, 10 LimPO) which were given the flushing treatment and 27 cows were given the non-flushing treatment. Treatments applied were T0 (Pennisetum purpurium + rice straw $\pm 30 \mathrm{~kg}$ ), T1 (Pennisetum purpurium + rice straw $\pm 30 \mathrm{~kg}+$ concentrate $2 \mathrm{~kg} /$ head / day). The results showed that the score of vulva change, behavior and uterus erection of the cow which were given the flushing and nonflushing treatments respectively were $3 ; 2 ; 2$; meanwhile the score of mucus secretion change of cow which were given the flushing treatment was 1 and non-flushing treatment was 1.5. The oestrous intensity of the cow which were given the flushing treatment have not shown clear performance on oestrous phase. The flushing treatment also did not give significant effect on the conception of the cow.
\end{abstract}

Key words: cow, flushing, oestrous intensity, and conception.

\begin{abstract}
ABSTRAK
Penelitian ini bertujuan untuk mengetahui intensitas birahi dan angka kebuntingan induk sapi potong yang diberi perlakuan flushing dan non flushing. Sebanyak 22 ekor induk sapi potong (12 ekor induk sapi SimPO, 10 ekor induk sapi LimPO) yang di flushing dan 27 ekor induk sapi potong (14 ekor induk sapi SimPO, 13 ekor induk sapi LimPO) yang diberi perlakuan non flushing. Perlakuan yang diujikan adalah T0 (rumput gajah+ jerami padi $\pm 30 \mathrm{~kg}$ ) dan $\mathrm{T} 1$ (rumput gajah+ jerami padi $\pm 30 \mathrm{~kg}+$ konsentrat $2 \mathrm{~kg} / \mathrm{ekor} / \mathrm{hari}$ ). Hasil penelitian menunjukkan bahwa skor perubahan vulva, tingkah laku dan ereksi uterus induk sapi potong yang diberi perlakuan flushing dan non flushing berturut-turut adalah 3;2;2 sedangkan skor perubahan sekresi lendir induk sapi potong yang diberi perlakuan flushing 1 dan non flushing yaitu 1,5. Intensitas birahi induk sapi potong yang diberi perlakuan flushing belum memperlihatkan penampilan jelas pada fase birahi. Perlakuan flushing juga tidak berpengaruh nyata terhadap angka kebuntingan induk sapi potong.
\end{abstract}

Kata kunci: induk sapi potong, flushing, intensitas birahi, dan angka kebuntingan.

\section{PENDAHULUAN}

Sapi potong merupakan salah satu komoditas peternakan penghasil daging yang mempunyai potensi untuk dikembangkan. Populasi ternak sapi potong mengalami peningkatan sebesar $5,21 \%$ dari 14,74 juta ekor pada tahun 2014 menjadi 15,49 juta pada tahun 2015, akan tetapi kondisi tersebut belum mampu mencukupi kebutuhan daging sapi dalam negeri (Direktorat Jenderal Peternakan dan
Kesehatan Hewan, 2015). Berbagai cara telah dilakukan oleh pemerintah untuk meningkatkan populasi sapi potong salah satunya melalui program impor indukan bunting agar mampu menghasilkan bibit bakalan yang berkualitas serta produktivitas meningkat sehingga kebutuhan daging sapi potong dapat tercukupi.

Faktor penyebab rendahnya populasi dan produktivitas sapi potong sebagian besar dipengaruhi oleh tatalaksana 
pemberian pakan dan perawatan kurang baik. Kualitas pakan yang kurang tercukupi untuk induk sapi potong akan menekan laju pertambahan bobot produktivitas menurun serta fungsi organ reproduksi terganggu. Pakan yang diberikan pada ternak berupa konsentrat dan hijauan yang mana ketersediaan hijauan mengalami penurunan terutama pada waktu musim kemarau. Berdasarkan kebutuhan bahan pakan ternak dapat tercukupi dari jerami padi, akan tetapi kebutuhan energi rendah hal ini disebabkan oleh kandungan serat kasar jerami padi yang sangat tinggi. Oleh sebab itu diperlukan suplementasi berupa pakan yang mengandung nutrisi cukup untuk mendukung produksi maupun perbaikan reproduksi induk sapi potong.

Salah satu metode pemberian pakan pada induk sapi potong adalah metode flushing. Flushing merupakan metode untuk memperbaiki kondisi tubuh ternak melalui perbaikan pakan sehingga ternak siap untuk melakukan proses reproduksi, antara lain bunting, beranak dan menyusui pedet. Perbaikan kondisi tubuh pada induk sapi potong sebelum dikawinkan dapat mengoptimalkan proses reproduksi ternak sehingga dapat mengurangi angka kawin berulang.

\section{MATERI DAN METODE}

Penelitian dilaksanakan pada bulan September 2015- Februari 2016 di kelompok tani ternak (KTT) Kabupaten Magelang. Analisis proksimat dilaksanakan di Laboratorium Ilmu Nutrisi Pakan, Fakultas Peternakan dan Pertanian Universitas Diponegoro, Semarang.
Materi yang digunakan dalam penelitian 22 ekor induk sapi potong (12 ekor induk sapi SimPO, 10 ekor induk sapi LimPO) yang di-flushing dan 27 ekor induk sapi potong (14 ekor induk sapi SimPO, 13 ekor induk sapi LimPO) yang diberi perlakuan non flushing milik kelompok tani ternak. Pemilihan induk sapi potong berdasarkan kondisi fisiologis yaitu tidak sedang bunting, telah mencapai pubertas serta dewasa tubuh ( $\geq 18$ bulan) dengan bobot badan 300-500 kg, sehat, reproduktivitas secara fisiologis normal minimal melahirkan 1 kali. Induk sapi potong diberi pakan sesuai dengan kebiasaan peternak (T0) dan pakan tambahan berupa konsentrat rumput gajah dan jerami padi $\pm 30 \mathrm{~kg}+$ konsentrat 2 kg/ekor/hari (T1).

Parameter yang diamati untuk mengetahui pengaruh pemberian pakan secara flushing dan non flushing pada induk sapi potong adalah intensitas birahi dan angka kebuntingan. Pengamatan parameter intensitas birahi induk sapi potong berdasarkan pemberian skor dengan interval 1-3 (skor 1 kurang jelas, skor 2 jelas dan skor 3 sangat jelas) terhadap induk sapi potong yang menampakkan birahi. Angka kebuntingan ditentukan berdasarkan hasil diagnosis kebuntingan melalui palpasi rektal (PKB) oleh inseminator dalam waktu 3 bulan setelah inseminasi buatan.

Data intensitas birahi yang sudah diperoleh kemudian diuji dengan uji median, angka kebuntingan menggunakan analisis chi-square. 
Perhitungan intensitas birahi menggunakan uji median dengan rumus sebagai berikut :

$$
X^{2} \text { hit }=\frac{n\left[\{(a d-b c)\}-\frac{n}{2}\right]^{2}}{(a+b)(c+d)(a+c)(b+d)}
$$

Perhitungan angka kebuntingan menggunakan uji chi-square $\left(\mathrm{X}^{2}\right)$ dengan rumus sebagai berikut :

$$
\chi^{2} \text { hit }=\sum \frac{(\mathrm{O}-\mathrm{E})^{2}}{\mathrm{E}}
$$

\section{Keterangan :}

$\mathrm{O}$ : nilai observasi yang telah didapatkan

$\mathrm{E}$ : nilai harapan yang telah didapatkan

\section{HASIL DAN PEMBAHASAN}

Kandungan nutrisi pakan flushing dan non flushing induk sapi potong dapat dilihat pada Tabel 1. Pada Tabel 1 bahwa pemberian pakan non flushing yang terdiri dari rumput gajah dan jerami kandungan TDN dan protein kasarnya rendah sedangkan serat kasarnya tinggi. Hal ini dimungkinkan pengaruh lama pemotongan hijauan tersebut. Rumput gajah dipanen pada saat umur 90 hari setelah tanam sedangkan jerami padi diberikan pasca pengambilan hasil utama padi. Djajanegara (1998) menyatakan bahwa semakin tua umur tanaman pada saat pemotongan, maka semakin berkurang kadar protein dan serat kasarnya semakin tinggi.

Tabel 1. Perbandingan kandungan nutrisi induk sapi potong yang di-flushing dan non flushing

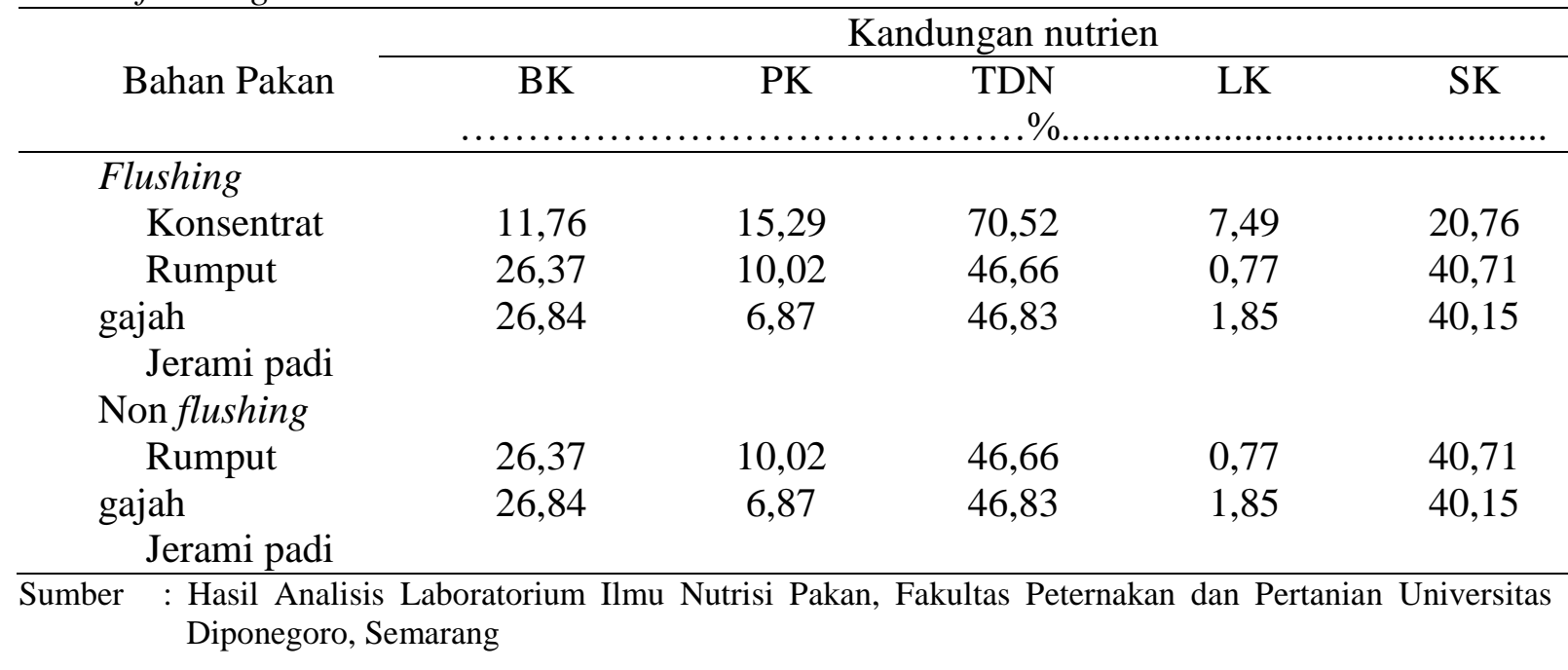

Pemberian pakan secara flushing dapat meningkatkan kandungan nutrien PK dan TDN dibandingkan pakan secara non flushing. Peningkatan PK dan TDN digunakan ternak sebagai energi untuk produksi maupun memperbaiki aktifitas reproduksi induk sapi potong. Aktifitas reproduksi pada induk sapi potong membutuhkan kandungan protein kasar sebesar 7\% (National Research Council, 2000). Sutiyono et al. (1999) menyatakan bahwa kualitas pakan khususnya protein merupakan perangsang yang baik untuk terjadinya ovulasi. Rendahnya kualitas pakan dalam tiga bulan awal setelah beranak terutama kandungan protein kasar (PK) merupakan penyebab tidak optimalnya periode birahi. Nutrisi ternak 
dalam jumlah dan kualitas yang cukup akan menjamin kelangsungan fungsi-fungsi dalam tubuh ternak termasuk fungsi reproduksi. Menurut Toelihere (1981) bahwa kebutuhan reproduksi tidak akan terganggu apabila kebutuhan nutrisi untuk kebutuhan hidup pokok sudah terpenuhi.

\section{Intensitas Birahi Induk Sapi Potong}

Berdasarkan penelitian yang telah dilakukan didapatkan hasil bahwa pada saat birahi berlangsung induk sapi potong yang di flushing dan non flushing tidak menunjukkan perbedaan yang nyata dengan rata-rata skoring intensitas tampilan birahi sama.

Tabel 2. Nilai median skor intensitas birahi induk sapi potong

\begin{tabular}{lcccc}
\hline \multirow{3}{*}{ Perlakuan } & \multicolumn{4}{c}{ Intensitas Tampilan Birahi } \\
\cline { 2 - 5 } & & & Tingkah & Ereksi \\
& Vulva & Lendir & Laku & Uterus \\
\hline Flushing & 3 & 1,5 & 2 & 2 \\
Non Flushing & 3 & 1 & 2 & 2
\end{tabular}

Keterangan : Skor 1 : tidak menunjukkan tanda-tanda birahi; skor 2 : menunjukkan tanda-tanda birahi namun kurang jelas; skor 3 : menunjukkan tanda-tanda birahi dengan jelas

\section{Perubahan Vulva}

Berdasarkan Tabel 2, skor perubahan vulva induk sapi potong SIMPO maupun LIMPO yang diberi perlakuan flushing dan non flushing sama yaitu 3 (Tabel 2). Hal ini menunjukkan bahwa penampilan perubahan vulva induk sapi potong yang diberi perlakuan flushing dan non flushing terlihat sangat jelas pada fase birahi dengan tampilan vulva yang relatif sama. Perubahan vulva tersebut disebabkan oleh pengaruh hormon estrogen yang dihasilkan oleh sel-sel yang membentuk dinding folikel. Estrogen merangsang penebalan dinding vagina dan peningkatan aliran darah menuju organ reproduksi sehingga alat kelamin bagian luar mengalami perubahan ukuran atau bengkak (Frandson, 1996). Perubahan warna vulva yang memerah, membengkak dan hangat pada fase estrus dipengaruhi oleh kadar protein dalam pakan yang diberikan secara flushing. Pakan merupakan faktor yang sangat berpengaruh terhadap reproduksi, kekurangan protein menyebabkan timbulnya birahi yang lemah, silent heat, anestrus, dan kawin berulang (Prihatno et al., 2013).

Perubahan vulva pada fase estrus disebabkan karena meningkatnya hormon estrogen, yang memicu detak jantung sehingga jantung memompa darah secara berlebihan akibatnya terjadi peningkatan suplai darah ke organ genital. Skor perubahan vulva induk sapi potong yang diberi pakan secara flushing dan non flushing memiliki skor yang sama, hal ini kemungkinan disebabkan oleh pemberian pakan rumput gajah dan jerami mencukupi untuk sintesis hormon reproduksi serta pemberian pakan secara flushing dapat memperbaiki kondisi organ reproduksi 
lebih baik. Khan et al. (2010) menambahkan bahwa kekurangan protein dalam ransum kemungkinan disebabkan oleh defisiensi asam amino yang berfungsi untuk biosintesis gonadotropin maupun hormon gonadal.

\section{Sekresi Lendir}

Skor sekresi lendir induk sapi potong yang diberi perlakuan flushing yaitu 1,5 sedangkan skor perlakuan non flushing yaitu 1 (Tabel 2.). Hal ini menunjukkan bahwa pemberian perlakuan flushing dapat meningkatkan sekresi lendir induk selama fase birahi. Konsumsi pakan yang rendah dapat menyebabkan terhambatnya pembelahan sel dan gangguan pertumbuhan, produksi maupun reproduksi.

Pemberian pakan mempengaruhi sintesa maupun pelepasan hormon dan kelenjar-kelenjar endokrin. Kebutuhan nutrisi pakan yang semakin tercukupi untuk kebutuhan pokok dan produksi, maka kebutuhan nutrisi untuk perkembangan dan perbaikan reproduksi juga tercukupi. Hal ini disebabkan karena pakan yang di makan ternak sebagian besar digunakan untuk sintesa hormon reproduksi. Pemberian pakan secara flushing dapat mempengaruhi sel granulosa dalam memproduksi estrogen dengan cara mengubah androgen menjadi estadiol melalui proses aromatisasi. Estrogen merupakan hormon yang berperan dalam menunjukkan tanda-tanda birahi. pada fase proestrus serviks mengalami relaksasi gradual dan semakin banyak mensekresikan mucus yang tebal dan berlendir dari sel-sel goblet pada serviks dan vagina anterior dan dari kelenjar- kelenjar uterus. Ketersediaan lemak dalam tubuh dibutuhkan untuk prekursor pembentukan steroid, sehingga mempercepat birahi (Khodijah et al., 2014).

\section{Tingkah Laku}

Skor tingkah laku induk sapi potong yang diberi perlakuan flushing dan non flushing yaitu 2 (Tabel 2.). Pemberian pakan dapat meningkatkan aktivitas hipothalamus dan sekresi GnRH sehingga terjadi perubahan-perubahan hormon ovarium dari alat reproduksi betina yang dapat merangsang timbulnya birahi. Ovarium menghasilkan hormon estrogen yang mempunyai peran penting dalam intensitas birahi (Abidin et al., 2012). Tingkah laku birahi ini dipengaruhi oleh hormon estrogen yang berperan besar dalam penampilan gejala-gejala birahi. Estrogen akan menstimulasi progesterone receptor di caudal ventromedial hypothalamus untuk mengaktifkan dopamin. Dopamin dihasilkan pada medial preoptic area (MPOA) karena regulasi oleh syaraf nitric oxide synthase (NOS) yang mengaktifkan tingkah laku birahi. Dopamin akan mempengaruhi ER $\alpha$ knock-out di otak dan otak akan mensekresikan banyaknya catecholamine yang akan mempengaruhi tingkah laku kawin (Wersinger dan Rissman, 2000). Yendraliza (2013) menyatakan bahwa tingkah laku ternak betina pada fase birahi antara lain nafsu makan menurun, gelisah, ekor terangkat dan melenguh. Tingkatan pemberian pakan dapat mempengaruhi sintesa maupun pelepasan hormon dan kelenjar-kelenjar endokrin. Pemberian pakan secara flushing 
secara tidak langsung dapat memberikan nutrisi tambahan untuk mensintesis hormon reproduksi. Protein intake rendah dapat memperlambat munculnya tingkah laku estrus atau disebut silent heat dan dapat mengurangi ketepatan konsepsi pada sapi pedaging.

\section{Ereksi Uterus}

Skor perubahan vulva induk sapi potong yang diberi perlakuan flushing dan non flushing secara keseluruhan induk sapi potong memperlihatkan adanya ereksi uterus yaitu 2 (Tabel 2.). Toelihere (1977) menyatakan bahwa ereksi uterus terjadi karena adanya kontraksi pada waktu perkawinan serta akibat suplai darah yang semakin meningkat pada saat birahi sehingga peningkatan tersebut menyebabkan sel-sel responsif terhadap rangsangan. Pemberian pakan secara flushing merupakan salah satu akibat rangsangan dari luar yang dapat mempengaruhi hypothalamus untuk mengaktifkan hipofisa untuk meningkatkan faktor pelepas FSH dalam proses partumbuhan dan pematangan folikel serta bekerjanya LH dalam merangsang terjadinya ovulasi.

Skor Tampilan Induk Sapi Potong

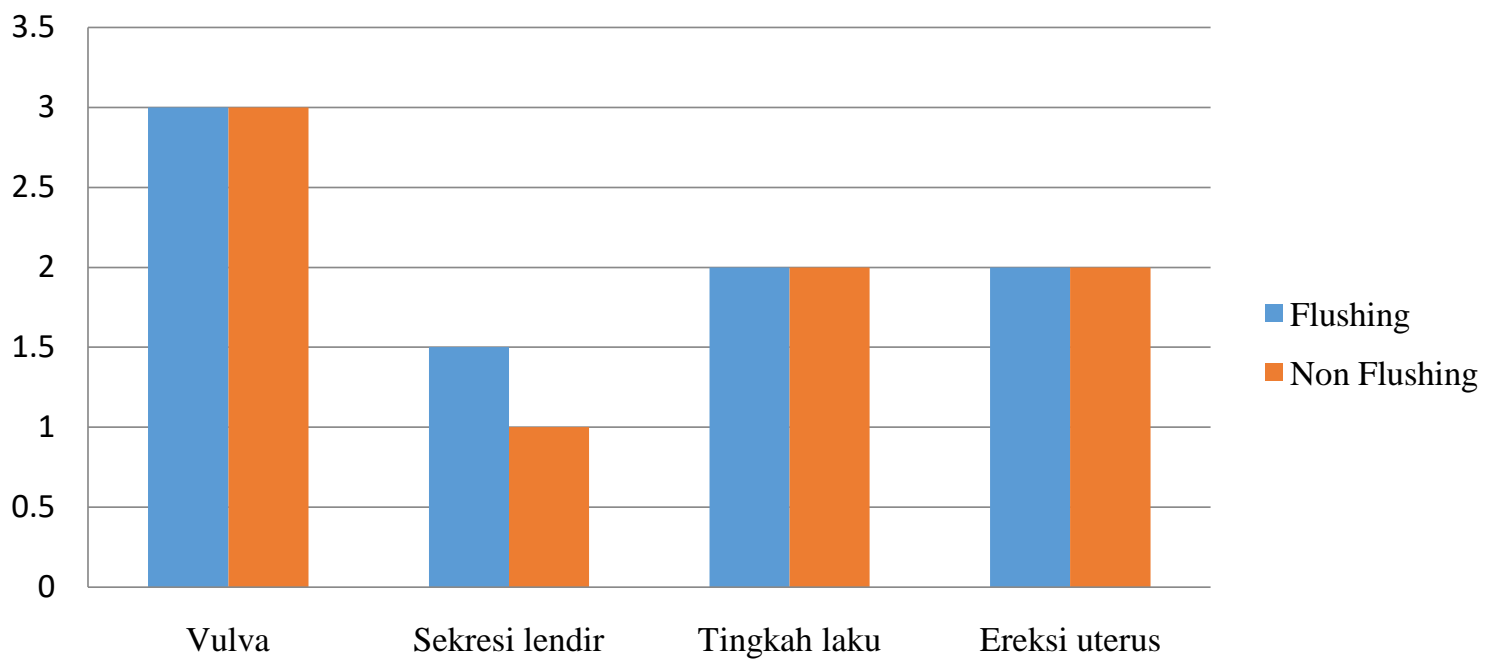

Gambar 1. Grafik perbedaan intensitas birahi induk sapi potong yang di flushing dan non flushing.

\section{Intensitas Birahi}

Berdasarkan
Gambar

Menunjukkan bahwa pemberian perlakuan flushing induk sapi potong terhadap intensitas birahi belum memperlihatkan penampilan jelas pada fase birahi. Hal ini dimungkinkan pemberian pakan kedua perlakuan tersebut belum dapat merangsang produksinya FSH. Kebutuhan pakan yang mencukupi pada induk sapi potong dapat memperlihatkan penampilan birahi yang jelas karena dapat merangsang hipothalamus, sehingga pituitary anterior dapat mengeluarkan FSH dan LH yang akan merangsang pertumbuhan folikel untuk menjadi folikel de Graaf (Toelihere, 1981). Kekurangan protein dalam ransum kemungkinan disebabkan oleh defisiensi asam amino yang berfungsi sebagai biosintesis gonadotropin dan hormon 
gonadal. Ketersediaan lemak dalam tubuh dibutuhkan untuk prekursor pembentukan steroid, sehingga mempercepat timbulnya birahi.

\section{Angka Kebuntingan Induk Sapi potong}

Berdasarkan hasil penelitian yang telah dilaksanakan, didapatkan hasil angka kebuntingan induk sapi potong yang di flushing dan non flushing (Tabel 3). Pemeriksaan keberhasilan inseminasi buatan (IB) dilakukan melalui palpasi rektal setelah 3 bulan pasca IB. Hasil perhitungan angka kebuntingan induk sapi potong sebesar 4,13. Hal ini menunjukkan bahwa pemberian perlakuan pakan secara flushing tidak menunjukkan adanya perbedaan yang nyata.
Pemberian flushing dengan menggunakan bahan pakan yang berkualitas baik selama 6-8 minggu akan mempengaruhi hipothalamus untuk merangsang pituitary anterior untuk meningkatkan faktor pelepas FSH dalam proses pertumbuhan dan pematangan folikel serta bekerjanya LH dalam merangsang terjadinya ovulasi (Sutiyono et al., 1999) Rendahnya konsentrasi hormon progesteron berdampak terhadap rendahnya angka konsepsi (Mann dan Lamming, 1992). Salah satu penyebab utama kematian embrio dini yang menjadi penyebab rendahnya angka konsepsi adalah tidak cukupnya fungsi luteal yang diindikasikan oleh rendahnya konsentrasi progesteron (Willard, et al. 2003).

Tabel 3. Angka kebuntingan induk sapi potong yang di -flushing dan non flushing

\begin{tabular}{lccc}
\hline \multirow{2}{*}{$\begin{array}{c}\text { Angka } \\
\text { Kebuntingan }\end{array}$} & \multicolumn{2}{c}{ Pemberian Pakan } & Jumlah \\
\cline { 2 - 3 } & Flushing & Non Flushing & 32 \\
\hline Bunting & $11(34,38 \%)$ & $21(65,62 \%)$ & 17 \\
\hline Tidak Bunting & $11(64,71 \%)$ & $6(35,29 \%)$ & 49 \\
\hline Jumlah & $22(44,90 \%)$ & $27(55,10 \%)$ & \\
\hline
\end{tabular}

Berdasarkan

Tabel

memperlihatkan bahwa pemberian pakan secara flushing belum dapat meningkatkan angka kebuntingan. Keberhasilan kebuntingan induk sapi potong dipengaruhi oleh beberapa faktor an-tara lain ketepatan peternak dalam mendeteksi birahi dan melaporkan petugas inseminator, ketepatan pelayanan inseminasi buatan pada puncak birahi, tingkat keterampilan inseminator, kesuburan induk sapi potong serta kualitas semen yang digunakan (Toelihere, 1993). Rendahnya angka kebuntingan disebabkan
3, selain kandungan nutrisi dalam pakan yang diberikan secara flushing kurang mencukupi sesuai kebutuhan ternak, keterampilan dan kecakapan inseminator juga mempengaruhi keberhasilan inseminasi buatan. Kasus yang terjadi selama di lapangan setelah peternak melapor pada pagi hari ketika malam sebelumnya induk sapi potong muncul tanda-tanda birahi, akan tetapi petugas inseminator tiba dilokasi pada sore hari akibatnya puncak birahi induk sapi telah selesai. Inseminasi dilakukan pada 
pertengahan masa estrus hingga pada akhir estrus, yaitu 9-18 jam setelah munculnya estrus atau diperkirakan 12-18 jam sebelum waktu ovulasi. Perkawinan pada awal estrus dan 6 jam sebelum ovulasi juga dapat menurunkan angka kebuntingan (Bearden dan Fuquay, 1980).

\section{KESIMPULAN}

Pemberian pakan secara flushing dan non flushing terhadap intensitas birahi induk sapi potong belum menunjukkan penampilan jelas pada fase birahi serta angka kebuntingan induk sapi potong tidak berpengaruh nyata.

\section{DAFTAR PUSTAKA}

Abidin, Z. Y. S. Ondho dan B. Sutiyono. 2012. Penampilan birahi sapi jawa berdasarkan poel 1, poel 2, poel 3 . Animal Agriculture Jurnal. 1 (2): 8692.

Bearden, H. J. and J.W. Fuquay. 1980. Apllied Animal Reproduction. Reston Publishing Company, Inc. A Prentice Hall Company, Virginia.

Frandson, R. D. 1996. Anatomi dan Fisiologi Ternak. Gadjah Mada University, Yogyakarta

(Diterjemahkan oleh B. Srigandono dan K. Praseno).

Khan, S., A. Thangavel, and S. Selvasubramaniyan. 2010. Blood biochemical profile in repeat breeding cows. Tamilnadu J. Vet. Anim. Sci. 4:90-102.
Khodijah, L., R. Zulihar, M. A. Wiryawan dan D. A. Astuti. 2014. Suplementasi minyak bunga matahari (Helianthus annuus) pada ransum pra kawin terhadap konsumsi nutrien, penampilan dan karakteristik estrus domba garut. JITV. 19 (1) : 9-16.

Mann, G.M. and G. E. Lamming. 1992. The influence of progesterone during early pregnancy in cattle. Reprod. Domest. Anim. 34:269-274.

Partodiharjo, S. 1980. Ilmu Reproduksi Hewan. Mutiara Sumber Wijaya, Jakarta.

Prihatno, A. Kusumawati., N. W. K. Karja dan B. Sumiarto. 2013. Profil Biokimia Darah Pada Sapi Perah Yang Mengalami Kawin Berulang. J. Kedokteran Hewan. 7 (1) : 29-31.

Sutiyono, Risko, E. T. Setiatin, B. Purboyo, C. M. S. Lestari dan R. Adiwinarti. 1999. Pengaruh flushing terhadap kecepatan dan lama birahi pada Domba yang diserentakkan birahinya menggunakan progestagen. Seminar Pusat Pengembangan Teknologi. Universitas Diponegoro. Semarang.

Toelihere, M. R. 1977. Fisiologi Reproduksi pada Ternak. Angkasa, Bandung.

Toelihere, M. R. 1993. Inseminasi Buatan pada Ternak. Angkasa, Bandung.

Wersinger, S. R. dan E. F. Rissman. 2000. Dopamine activates masculine sexual behavior independent of the estrogen 
receptor $\alpha$. Journal of neuroscience. 20 (11): 4248-4254.

Willard, S., S. Gandy, S. Bowers, K. Graves, A. Elias, and C. Whisnant. 2003. The effects of GnRH administration post insemination on serum concentrations of progesterone and pregnancy rates in dairy cattle exposed to mild summer heat stress. Theriogenology 59:1799-1810.

Yendraliza. 2013. Pengaruh nutrisi dalam pengelolaan reproduksi ternak (studi literature). Kutubkhanah. 16 (1) : 2026. 